\title{
Reaction of diphenyl diselenide with hydrogen peroxide and inhibition of delta-aminolevulinate dehydratase from rat liver and cucumber leaves
}

M. Farina, N.B.V. Barbosa, C.W. Nogueira, V. Folmer, G. Zeni, L.H. Andrade, A.L. Braga and J.B.T. Rocha
Departamento de Química, Centro de Ciências Naturais e Exatas, Universidade Federal de Santa Maria, Santa Maria, RS, Brasil

\section{Correspondence \\ J.B.T. Rocha \\ Departamento de Química \\ Centro de Ciências Naturais e Exatas \\ Universidade Federal de Santa Maria \\ 97105-900 Santa Maria, RS \\ Brasil \\ Fax: + 55-52-20-8031 \\ E-mail: jbtrocha@ base.ufsm.br \\ Research supported by FAPERGS and CNPq (N o. 523761/95-3). M. Farina was the recipient of a FAPERGS \\ fellowship. J.B.T. Rocha and \\ V. Folmer are recipients of $\mathrm{CNPq}$ \\ fellowships.}

Received December 5, 2000

Accepted February 14, 2002

\section{Abstract}

The interaction of the product of $\mathrm{H}_{2} \mathrm{O}_{2}$ and $(\mathrm{PhSe})_{2}$ with $\delta$-aminolevulinate dehydratase ( $\delta$-ALA-D) from mammals and plants was investigated. $(\mathrm{PhSe})_{2}$ inhibited rat hepatic $\delta$-ALA-D with an $\mathrm{IC}_{50}$ of $10 \mu \mathrm{M}$ but not the enzyme from cucumber leaves. The reaction of $(\mathrm{PhSe})_{2}$ with $\mathrm{H}_{2} \mathrm{O}_{2}$ for $1 \mathrm{~h}$ increased the inhibitory potency of the original compound and the $\mathrm{IC}_{50}$ for animal $\delta$-ALA-D inhibition was decreased from 10 to $2 \mu \mathrm{M}$. $\delta$-ALA-D from cucumber leaves was also inhibited by the products of reaction of $(\mathrm{PhSe})_{2}$ with $\mathrm{H}_{2} \mathrm{O}_{2}$ with an $\mathrm{IC}_{50}$ of $4 \mu \mathrm{M}$. The major product of reaction of $(\mathrm{PhSe})_{2}$ with $\mathrm{H}_{2} \mathrm{O}_{2}$ was identified as seleninic acid and produced an intermediate with a $\lambda_{\max }$ at $265 \mathrm{~nm}$ after reaction with t-BuSH. These results suggest that the interaction of $(\mathrm{PhSe})_{2}$ with mammal $\delta$-ALA-D requires the presence of cysteinyl residues in close proximity. Two cysteine residues in spatial proximity have been recently described for the mammalian enzyme. Analysis of the primary structure of plant $\delta$-ALA-D did not reveal an analogous site. In contrast to $(\mathrm{PhSe})_{2}$, seleninic acid, as a result of the higher electrophilic nature of its selenium atom, may react with additional cysteinyl residue(s) in mammalian $\delta$-ALA-D and also with cysteinyl residues from cucumber leaves located at a site distinct from that found at the $\mathrm{B}$ and $\mathrm{A}$ sites in mammals. Although the interaction of organochalcogens with $\mathrm{H}_{2} \mathrm{O}_{2}$ may have some antioxidant properties, the formation of seleninic acid as a product of this reaction may increase the toxicity of organic chalcogens such as $(\mathrm{PhSe})_{2}$.

\section{Introduction}

The molecular mechanisms underlying selenium toxicity are still not thoroughly understood; however, several decades ago Painter (1) emphasized that the toxicity of inorganic selenium could be related to the oxidation of thiols with the concomitant formation of derivatives of the RSSeSR type

\section{Key words} - $\delta$-Aminolevulinate dehydratase - Diphenyl diselenide

- Seleninic acid (selenotrisulfides). After the theoretical Painter proposal, interaction of thiols with inorganic selenium was confirmed experimentally by various investigators (2-5).

Organic selenocompounds such as selenocystine and a variety of diselenides can also react with thiols such as cysteine, dithiothreitol, and reduced glutathione to produce selenocysteine and selenols, respectively, and di- 
sulfides $(6,7)$. Although some decades ago the reduction of diselenides to selenols by reaction with thiols was considered to be of physiological significance (6), it is now apparent that the physiological role of selenium involves the participation at the active center of glutathione peroxidase and phospholipid hydrogen glutathione peroxidase $(8,9)$. In these two enzymes the selenium is part of a residue of selenocysteine (10) and during the catalytic cycle of the enzyme the selenol group is probably oxidized by peroxide to a selenenic acid. In subsequent steps, selenol is regenerated by the reaction of selenenic acid with reduced glutathione $(8,9)$. Interestingly, it has been demonstrated that simple diselenides such as diphenyl diselenide $(11,12)$ and the antioxidant selenocompound, ebselen (13-15) accelerate the rate of peroxide reduction by a variety of thiols in a reaction similar to that catalyzed by glutathione peroxidase. However, in addition to taking part in these types of reactions, simple organochalcogens such as diphenyl diselenide catalytically accelerate the rate of thiol oxidation even in the absence of $\mathrm{H}_{2} \mathrm{O}_{2}$ $(16,17)$. Although the peroxidase-like activity of diselenides may account for their antioxidant properties, the sulfhydryl-disulfide exchange catalyzed by these compounds may contribute to their toxic properties by the oxidation of sulfhydryl proteins.

$\delta$-Aminolevulinate dehydratase $(\delta$-ALAD) or porphobilinogen synthase is an enzyme sensitive to sulfhydryl-blocking agents (18-22) and participates in the second step of heme, chlorophyll and corrin biosynthesis. This enzyme catalyzes the condensation of two molecules of 5-aminolevulinic acid to porphobilinogen (23), thus playing a fundamental role in animals and in photosynthesizing organisms. Consequently, $\delta$-ALA-D inhibition may impair heme biosynthesis (24) and can result in the accumulation of ALA, which may affect the aerobic metabolism and may have some prooxidant activity $(25,26)$. Although the basic mechanism of catalysis seems to be similar in all phyla
(23), the enzyme obtained from mammals and plants exhibits some structural differences $(23,27)$. Recently, we reported that $\delta$ ALA-D from plants, in marked contrast to $\delta$ ALA-D from mammals, was not inhibited by diphenyl diselenide (16). The different sensitivity of the animal and plant enzymes to inhibition by diphenyl diselenide was tentatively associated with differences in the primary structure of $\delta$-ALA-D from these sources $(21,23,27)$.

As stated previously, a variety of organochalcogens exhibit peroxidase-like activity and during the catalytic cycle of $\mathrm{H}_{2} \mathrm{O}_{2}$ reduction intermediates such as $\mathrm{RSeOH}$ and $\mathrm{RSeOOH}$ are certainly formed and later reduced by thiols to the original compound $(8,9)$. Although the formation of selenocysteinenic acid at the active site of glutathione peroxidase is presumed to be of physiological significance during $\mathrm{H}_{2} \mathrm{O}_{2}$ decomposition by reduced glutathione, the reaction of organochalcogens with $\mathrm{H}_{2} \mathrm{O}_{2}$ in vivo may yield more reactive compounds with distinct toxicological properties.

However, to the best of our knowledge, no previous study has investigated the interaction between peroxides and diphenyl diselenide with regard to the reactivity of the products of this reaction towards biomolecules. In an attempt to better understand the toxicology of diphenyl diselenide, a simple organochalcogen compound that plays an important role as an electrophilic reagent for the synthesis of a variety of potential pharmacologically active compounds $(28,29)$, we examined the interaction of this compound with $\mathrm{H}_{2} \mathrm{O}_{2}$ and that of the product, seleninic acid, with $\delta$-ALA-D from mammals and plants.

\section{Material and Methods}

\section{Tissue preparation}

Adult rats from our own breeding colony were maintained in an air conditioned room $\left(20-25^{\circ} \mathrm{C}\right)$ under natural lighting conditions, 
with water and food (Guabi, Ribeirão Preto, SP, Brazil) ad libitum. Animals were anesthetized with ether and killed by decapitation. The livers were quickly removed, placed on ice and homogenized in 7 volumes of 150 $\mathrm{mM} \mathrm{NaCl}$. The homogenate was centrifuged at $4,000 \mathrm{~g}$ at $4^{\circ} \mathrm{C}$ for $10 \mathrm{~min}$ to yield a lowspeed supernatant fraction (S1) that was used for the enzyme assay. Cucumber seeds were germinated for 5 to 7 days at $25^{\circ} \mathrm{C}$. Leaves were homogenized in 5 volumes of medium containing $10 \mathrm{mM}$ Tris- $\mathrm{HCl}, \mathrm{pH}$ 9.0. The homogenate was then centrifuged as described for animal tissue, and the low-speed supernatant (S1) obtained was used for the enzyme assay. Blood $\delta$-ALA-D from pig liver was partially purified as described by Emanuelli et al. (30).

\section{Reaction of PhSeSePh with hydroperoxide}

To study the effect of the products of 4 nmol to $1.2 \mu \mathrm{mol}$ of $\mathrm{PhSeSePh}$ with $\mathrm{H}_{2} \mathrm{O}_{2}$ (125 $\mu \mathrm{mol})$, the reaction was carried out for $1 \mathrm{~h}$ at $39^{\circ} \mathrm{C}$. Then, catalase (200 units) was added to eliminate the remaining $\mathrm{H}_{2} \mathrm{O}_{2}$ and the enzymatic reaction was carried out as described above.

To characterize the product of the reaction described above, $100 \mu \mathrm{mol}$ of $\mathrm{PhSeSePh}$ was allowed to react with $4.4 \mathrm{mmol}$ of $\mathrm{H}_{2} \mathrm{O}_{2}$ at $39^{\circ} \mathrm{C}$. After $4 \mathrm{~h}$, the organic phase was extracted into ethyl acetate and, after solvent evaporation, the melting point of the resulting solid was obtained $\left(121-122^{\circ} \mathrm{C}\right)$. The resulting compound, tentatively identified as benzeneseleninic acid $\left(\mathrm{PhSeO}_{2} \mathrm{H}\right)$, was dissolved in $60 \%$ dioxane buffered with phosphate buffer, $\mathrm{pH}$ 6.0, and reacted with t$\mathrm{BuSH}$ at a ratio of $1: 4(\mathrm{~mol} / \mathrm{mol} \mathrm{SH})$ as described by Kice and Lee (29). The formation of the product was also confirmed by analysis of the ${ }^{1} \mathrm{H}$ - and ${ }^{13} \mathrm{C}-\mathrm{NMR}$ spectra.

\section{Enzyme assay}

Rat $\delta$-ALA-D activity was assayed ac- cording to the method of Sassa (31) by measuring the rate of product (porphobilinogen) formation except that $84 \mathrm{mM}$ potassium phosphate buffer, pH 6.4, and $2.5 \mathrm{mM} \delta$-ALA were used. For the plant enzyme, the medium contained $100 \mathrm{mM}$ Tris-HCl, pH 9.0, 2 $\mathrm{mM} \mathrm{MgCl} 2$ and $3.6 \mathrm{mM}$ ALA. The products of reaction of $\mathrm{PhSeSePh}$ and hydroperoxide or $\mathrm{PhSeSePh}$ alone were preincubated for 10 min with the enzyme preparations and then the $\delta$-ALA-D reaction was initiated by adding substrate. Incubations were carried out for $1 \mathrm{~h}$ at $39^{\circ} \mathrm{C}$ for the animal enzyme and at $35^{\circ} \mathrm{C}$ for the plant enzyme. The enzyme reaction product was determined using modified Ehrlich's reagent at $555 \mathrm{~nm}$, with a molar absorption coefficient of $6.1 \times 10^{4} \mathrm{M}^{-1}$ for the Ehrlich-porphobilinogen salt.

\section{Protein quantification}

Protein was measured by the method of Bradford (32) using bovine serum albumin as standard.

\section{$\mathrm{IC}_{50}$ determination}

The $\mathrm{IC}_{50}$ for in vitro inhibition of liver and plant $\delta$-ALA-D activity was calculated by the method of Dixon and Webb (33).

\section{Statistical analysis}

Data were analyzed by two- or four-way ANOVA as indicated in legend to the figures. Significant main effects or low level interactions were only considered when higher order interactions were not statistically significant.

\section{Results}

In the presence of liver supernatant, addition of $\mathrm{H}_{2} \mathrm{O}_{2}$ did not change the effect of $\mathrm{PhSeSePh}$ on $\delta$-ALA-D (Figure 1). At the concentrations studied, $\mathrm{H}_{2} \mathrm{O}_{2}$ did not affect $\delta$-ALA-D, possibly due to the presence of 
catalase in the liver preparation. The presence of catalase under the conditions of the $\delta$-ALA-D assay was determined by titrating $\mathrm{H}_{2} \mathrm{O}_{2}$ with $\mathrm{KMnO}_{4}$. The concentration of $\mathrm{H}_{2} \mathrm{O}_{2}$ was reduced to $98-100 \%$ of the initial concentration during the 10-min preincubation (data not shown).

In order to circumvent the degradation of $\mathrm{H}_{2} \mathrm{O}_{2}$ by catalase, $\mathrm{PhSeSePh}$ was reacted with $\mathrm{H}_{2} \mathrm{O}_{2}$ before the addition of liver or plant preparations. Excess $\mathrm{H}_{2} \mathrm{O}_{2}$ was degraded by adding purified catalase. ANOVA revealed a significant main effect of $\mathrm{PhSeSePh}$ concentration, pre-reaction with $\mathrm{H}_{2} \mathrm{O}_{2}$ and source of $\delta$-ALA-D (all $\mathrm{P}<0.01$ ).

Figure 1. Effect of $\mathrm{H}_{2} \mathrm{O}_{2}$ and $\mathrm{PhSeSePh}$ on rat liver $\delta$-ALA-D. $\mathrm{H}_{2} \mathrm{O}_{2}$ was added at the same time as the liver supernatant to medium containing $84 \mathrm{mM}$ sodium phosphate buffer, $\mathrm{pH}$ 6.4. After $10 \mathrm{~min}$ of preincubation, the $\delta$-ALA-D reaction was started by adding ALA to a final concentration of $2.5 \mathrm{mM}$ (control, circles), $0.5 \mu \mathrm{M}$ PhSeSePh (squares), and $4 \mu \mathrm{M}$ PhSeSePh (triangles). Two-way ANOVA yielded a significant main effect of $\mathrm{PhSeSePh}$ concentration $[F(2,54)=12.3, P<0.01]$. The main effects of $\mathrm{H}_{2} \mathrm{O}_{2}$ and $\mathrm{PhSeSePh} \times \mathrm{H}_{2} \mathrm{O}_{2}$ interaction were not significant.

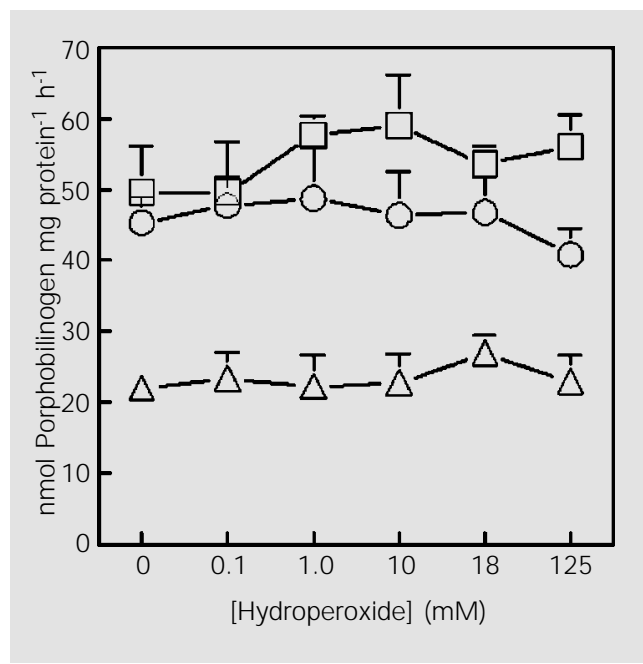

Second and third order interactions were also significant (all $\mathrm{P}<0.03$ ). As illustrated in Figure $2 \mathrm{~A}, \mathrm{PhSeSePh}$ inhibited rat liver $\delta$ ALA-D, although the $\delta$-ALA-D from cucumber leaves was inhibited only when $\mathrm{PhSeSePh}$ was pretreated with $\mathrm{H}_{2} \mathrm{O}_{2}$ (Figure $2 \mathrm{~B})$. The $\mathrm{IC}_{50}$ for plant $\delta$-ALA-D after reaction of $\mathrm{PhSeSePh}$ with $\mathrm{H}_{2} \mathrm{O}_{2}$ was $4 \mu \mathrm{M}$. The $\mathrm{IC}_{50}$ for liver inhibition by $\mathrm{PhSeSePh}$ was 10 $\mu \mathrm{M}$ and the value decreased to $2 \mu \mathrm{M}$ after reaction of $\mathrm{H}_{2} \mathrm{O}_{2}$ with $\mathrm{PhSeSePh}$ before addition of the enzyme. Similar results were obtained with partially purified $\delta$-ALA-D from pig blood (data not shown). Dithiothreitol, a reducing and sulfhydryl-protecting agent, at $2 \mathrm{mM}$ blocked the effect of $\mathrm{PhSeSePh}$ or the products of the reaction of $\mathrm{PhSeSePh}$ with $\mathrm{H}_{2} \mathrm{O}_{2}$. This occurred in every case in which inhibition of $\delta$-ALA-D was detected (Figure 2). The compound synthesized for UV and ${ }^{1} \mathrm{H}-\mathrm{NMR}$ spectroscopic characterization was also tested as a $\delta$-ALA$\mathrm{D}$ inhibitor. The inhibitory potency of the synthesized compound was similar to that of the compound(s) generated in situ in the mammalian and cucumber $\delta$-ALA-D assay (data not shown).

Reaction of $\mathrm{PhSeSePh}$ with excess $\mathrm{H}_{2} \mathrm{O}_{2}$ can result in the formation of selenenic and seleninic derivatives of $\mathrm{PhSeSePh}(29,34,35)$. The major product of reaction between
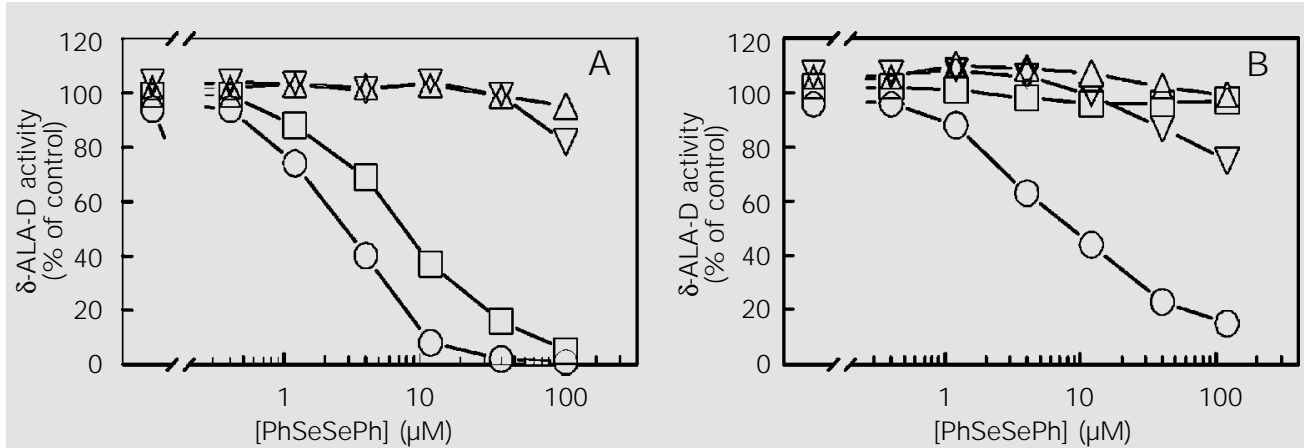

Figure 2. Effect of PhSeSePh on rat liver (A) and cucumber leaf (B) $\delta$-ALA-D. Reaction of $\mathrm{PhSeSePh}$ with $\mathrm{H}_{2} \mathrm{O}_{2}$ was carried out for $1 \mathrm{~h}$ and the remaining $\mathrm{H}_{2} \mathrm{O}_{2}$ was eliminated by adding catalase (200 units). Preincubation of enzyme with $\mathrm{PhSeSePh}$ or products from reaction of $\mathrm{PhSeSePh}$ and $\mathrm{H}_{2} \mathrm{O}_{2}$ was initiated by adding liver $(\mathrm{A})$ or plant (B) supematants to reaction mixtures containing $84 \mathrm{mM}$ phosphate buffer, pH 6.4 (liver), or 50 mM Tris buffer, pH 9.0 (plant). The $\delta$-ALA-D reaction was started 10 min later by adding ALA (final concentration 2.5 or $3.6 \mathrm{mM}$, respectively). Control (circles); $125 \mathrm{mM} \mathrm{H}_{2} \mathrm{O}_{2}$ (squares); $2 \mathrm{mM}$ dithiothreitol (DTT, triangles); $125 \mathrm{mM} \mathrm{H} \mathrm{O}_{2}$ and $2 \mathrm{mM}$ DTT (inverted triangles). Four-way ANOVA yielded a variety of significant main and interaction effects, which, however, are not presented because the fourth order interaction $(7 \mathrm{PhSeSePh}$ concentration $\times 2$ reaction with $\mathrm{H}_{2} \mathrm{O}_{2} \times 2 \delta$-ALA-D source $\times 2 \mathrm{DTT}$ concentration) was significant $[\mathrm{F}(6,168)=32.3, \mathrm{P}<0.01]$. This indicates that the effect of PhSeSePh varied depending on the source of the enzyme, on the previous reaction with $\mathrm{H}_{2} \mathrm{O}_{2}$, and on the presence or absence of DTT. 
$\mathrm{PhSeSePh}$ and $\mathrm{H}_{2} \mathrm{O}_{2}$ was isolated and showed a melting point of $120-121^{\circ} \mathrm{C}$, in agreement with published values for benzeneseleninic acid $(29,34)$. The product was then reacted with t-BuSH as described by Kice and Lee (29). This generated an intermediate having a $\lambda_{\max }$ at $265 \mathrm{~nm}$ (Figure 3, curve B) and was first assumed to be the thiolseleninate $\mathrm{PhSe}(\mathrm{O}) \mathrm{SR}$. After $1 \mathrm{~h}$ (Figure 3, curve C), the concentration of this intermediate decreased. This was expected because after its initial formation thiolseleninate reacts with the excess of $\mathrm{t}-\mathrm{BuSH}$ to initiate a reaction sequence leading to PhSeSR and RSSR (29). The formation of benzeneseleninic acid as the major product of reaction of $\mathrm{H}_{2} \mathrm{O}_{2}$ and diphenyl diselenide was confirmed by analysis of the ${ }^{1} \mathrm{H}-\mathrm{NMR}$ spectrum. In fact, the ${ }^{1} \mathrm{H}$-NMR spectrum of the diphenyl diselenide gives rise to a multiplet at 7.1-7.5 $\delta$ in the aromatic region (Figure 4A). In contrast, the ${ }^{1} \mathrm{H}-\mathrm{NMR}$ spectrum of the benzeneseleninic acid gives rise to a multiplet at 7.4-7.8 $\delta$ in the aromatic region (Figure 4B). Taken together, these data lead us to conclude that the major product of $\mathrm{PhSeSePh}$ with $\mathrm{H}_{2} \mathrm{O}_{2}$ is benzeneseleninic acid. Additional support for the formation of seleninic acid after reaction of $\mathrm{PhSeSePh}$ with $\mathrm{H}_{2} \mathrm{O}_{2}$ was obtained by ${ }^{13} \mathrm{C}$-NMR spectroscopy. The ${ }^{13} \mathrm{C}-\mathrm{NMR}$ spectrum of the diphenyl diselenide showed chemical shifts of carbons between 121 and $130 \delta$ and the product of reaction between $\mathrm{PhSeSePh}$ and $\mathrm{H}_{2} \mathrm{O}_{2}$ showed chemical shifts between 127 and $131 \delta$. This difference could be explained by the effect of the seleninic group present in this structure and the absence of this group in the structure of diphenyl diselenide.

\section{Discussion}

$\mathrm{PhSeSePh}$ and benzeneseleninic acid $\left(\mathrm{PhSeO}_{2} \mathrm{H}\right)$ inhibited $\delta$-ALA-D by oxidizing cysteinyl residues essential for enzyme activity, since dithiothreitol abolished the inhibition caused by these compounds. How- ever, the reactivity of these compounds varied depending on the enzyme source. $\mathrm{PhSeSePh}$ inhibited only the mammalian enzyme, while $\mathrm{PhSeO}_{2} \mathrm{H}$ inhibited $\delta$-ALA-D from all sources. Furthermore, the potency of benzeneseleninic acid was higher on the rat enzyme than that of $\mathrm{PhSeSePh}$, which is consistent with the moderately strong oxidant properties of aromatic seleninic acids (29). Consequently, it is possible that, as a result of the higher electrophilicity of the $\mathrm{Se}$ atom in $\mathrm{PhSeO}_{2} \mathrm{H}$, the compound reacted more rapidly and/or with less reactive cysteinyl residues in mammalian and plant $\delta$-ALA-D.

The divergent response of the plant enzyme to diphenyl diselenide when compared to mammalian $\delta$-ALA-D is presumably related to differences in the primary structure of these enzymes, especially in the ion-binding regions. The mammalian enzyme possesses two distinct classes of $\mathrm{Zn}^{2+}$-binding sites, the class required for catalytic activity or the A site, that possesses one cysteinyl residue $(23,36)$, and the other $\mathrm{Zn}^{2+}$-binding site, that possesses four cysteine residues

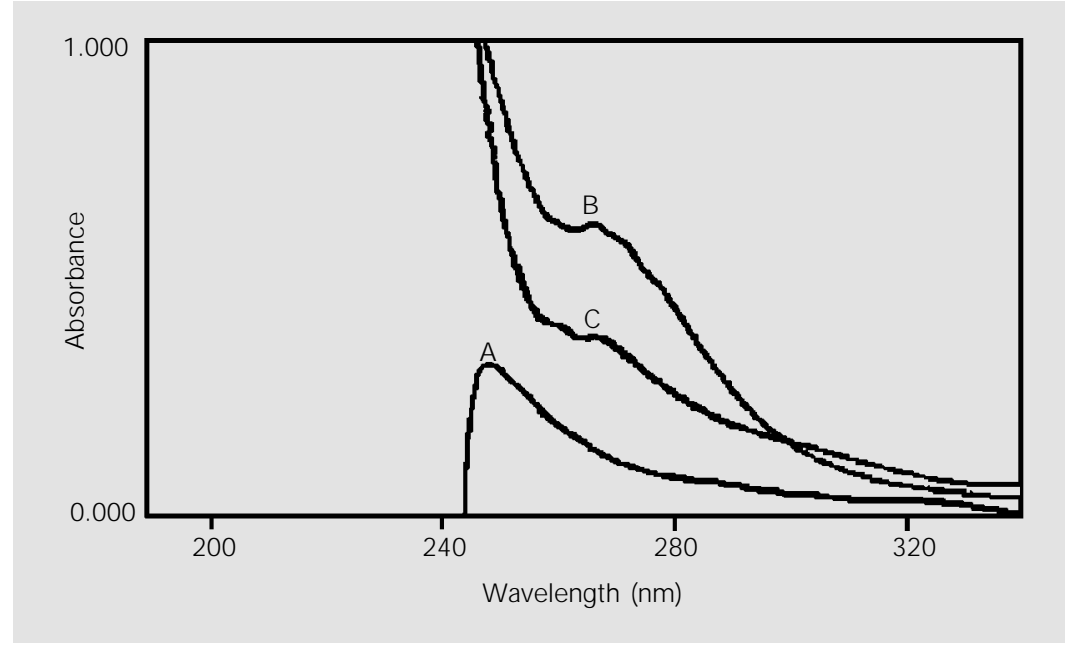

Figure 3. Characterization of the reaction of 2-methyl-2-propanethiol (t-BuSH) with the product of reaction of $\mathrm{PhSeSePh}$ with $\mathrm{H}_{2} \mathrm{O}_{2}$. Benzeneseleninic acid reacted with t-BuSH in $60 \%$ dioxane and $25 \mathrm{mM}$ potassium phosphate buffer, pH 6.0. Curves: A, $20 \mu \mathrm{mol} t-B u S H$; $\mathrm{B}, 5 \mu \mathrm{mol} \mathrm{PhSeO}{ }_{2} \mathrm{H}+20 \mu \mathrm{mol}$ t-BuSH, immediately after thiol addition; $\mathrm{C}, 5 \mu \mathrm{mol} \mathrm{PhSeO}_{2} \mathrm{H}$ $+20 \mu \mathrm{mol}$ t-BuSH after 60 min. For curve $A$ the reference cuvette contained $60 \%$ dioxane and phosphate buffer, while in curves $\mathrm{B}$ and $\mathrm{C}$ the reference cuvettes contained the same concentration of $\mathrm{PhSeO}_{2} \mathrm{H}$ as the sample cuvette. 
(37). In the plant enzyme, no cysteine residues were found in the homologous regions implicated in $\mathrm{Zn}^{2+}$ binding in mammalian $\delta$ ALA-D. However, $\delta$-ALA-D from different plant species has approximately four cysteine residues and is inhibited by classical sulfhydryl reagents such as iodoacetamide and N-ethylmaleimide (27). In the present
Figure $4 .{ }^{1} \mathrm{H}$ - and ${ }^{13} \mathrm{C}-\mathrm{NMR}$ spectra of PhSeSePh and of the product of reaction of $\mathrm{PhSeSePh}$ with $\mathrm{H}_{2} \mathrm{O}_{2}$. The ${ }^{1} \mathrm{H}-\mathrm{NMR}$ spectra of $\mathrm{PhSeSePh}$ and of the product of reaction of $\mathrm{PhSeSePh}$ with $\mathrm{H}_{2} \mathrm{O}_{2}$ are presented in $\mathrm{A}$ and $\mathrm{C}$, respectively. The ${ }^{13} \mathrm{C}-\mathrm{NM} \mathrm{R}$ spectra of PhSeSePh and of the product of reaction of $\mathrm{PhSeSePh}$ with $\mathrm{H}_{2} \mathrm{O}_{2}$ are presented in $\mathrm{B}$ and $\mathrm{D}$. Compounds were dissolved in $\mathrm{CDCl}_{3} / \mathrm{D}_{2} \mathrm{O}$ and then analyzed with a Bruker DPX-400 (400 $\mathrm{MHz}$ ) spectrometer.
A

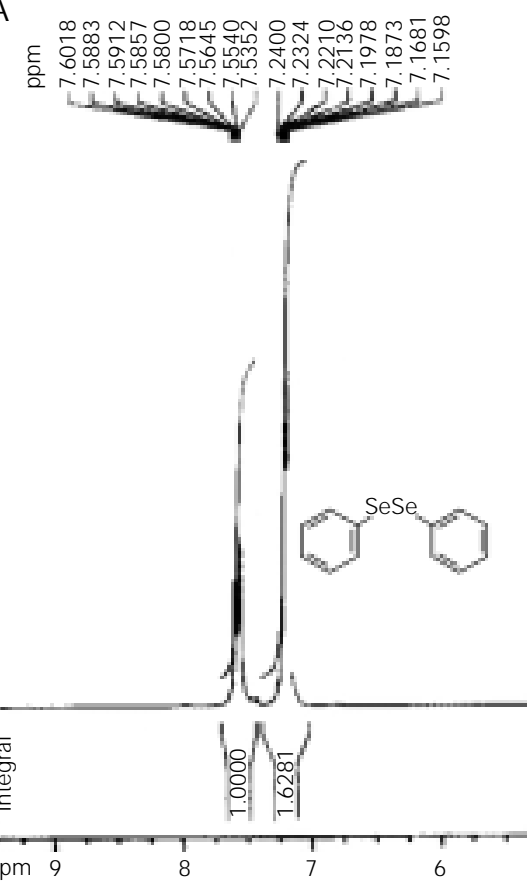

C
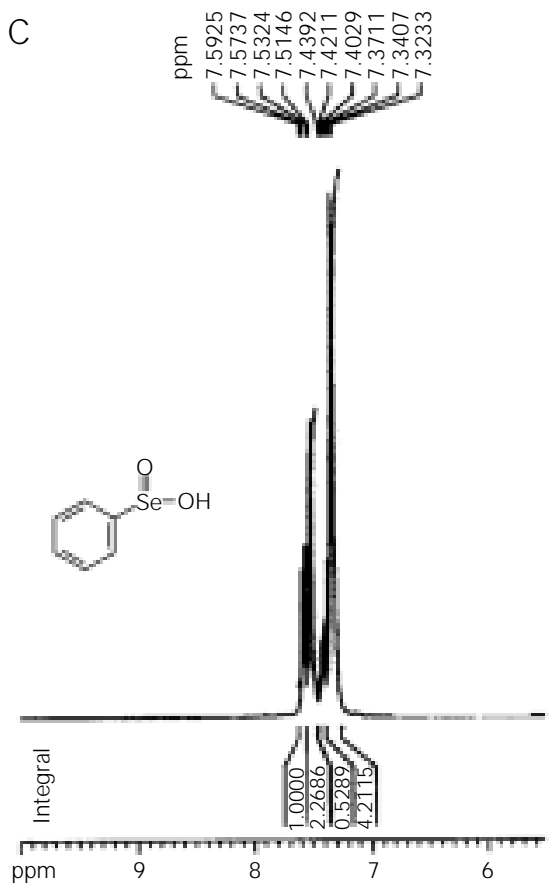

B
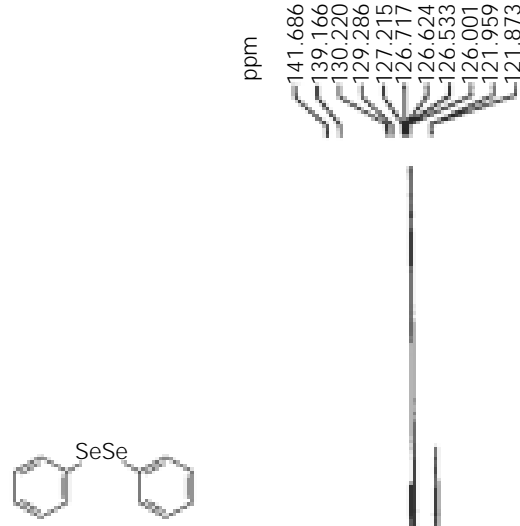

흥

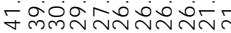

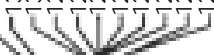

흘

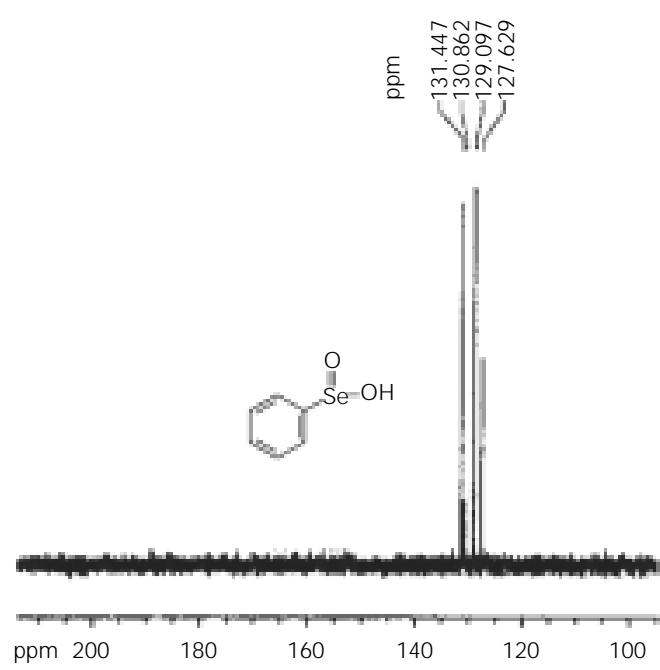

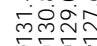

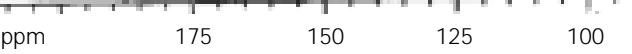

D 
study, $\mathrm{PhSeSePh}$ inhibited mammalian $\delta$ ALA-D with a relatively high potency but had a negligible effect on the plant enzyme. Tentatively, these differences can be explained by the fact that the mammalian enzyme possesses two cysteine residues in spatial proximity at the active site of the enzyme (21), while the plant enzyme does not possess such analogous residues. In view of this, we propose a scheme to interpret the oxidation of mammalian $\delta$-ALA-D by $\mathrm{PhSeSePh}$ (see below):

The first step involves the formation of an unstable intermediary of the E-Cys-S$\mathrm{SePh}$ type and $\mathrm{PhSeH}$. Then, in a subsequent step, a less reactive cysteinyl residue (represented as Cys**-SH in the scheme) due to its close proximity to the more reactive residue attacks the sulfur atom of the E-Cys*-S$\mathrm{SePh}$, producing the oxidized enzyme and a second molecule of $\mathrm{PhSeH}$. Support for this scheme has also been obtained using low molecular weight thiol-containing substances and dithiothreitol (a dithiol) was found to be a better substrate than cysteine or glutathione (monothiols) for the oxidation catalyzed by organodiselenides $(7,38)$. The $\mathrm{PhSeH}$ formed after the reaction with thiols is oxidized back to $\mathrm{PhSeSePh}$ by atmospheric $\mathrm{O}_{2}$. In fact, the regeneration of $\mathrm{PhSeSePh}$ after reaction with $\mathrm{O}_{2}$ helps to explain the previous observation that the inhibitory potency of $\mathrm{PhSeSePh}$ towards rat $\delta$-ALA-D decreases considerably in an anaerobic atmosphere (16). The inhibitory effect of $\mathrm{PhSeO}_{2} \mathrm{H}$ on mammalian $\delta$-ALA-D can be mediated by a direct oxidation of Cys*-SH and Cys**-SH. Oxidation of other less reactive cysteinyl residues other than those shown in the scheme cannot be ruled out.

In the present study, we showed that the product of $\mathrm{PhSeSePh}$ with $\mathrm{H}_{2} \mathrm{O}_{2}$ is more inhibitory for $\delta$-ALA-D than the parent selenide compound. In analogy to the proposed glutathione peroxidase catalytic cycle $(8,9)$, where the Se atom at the active site of the enzyme goes from the selenol to a still not isolated $(39,40)$ but presumed selenenic form, the peroxidase-like activity of diselenides probably involves the formation of a seleninic intermediary during the reduction of peroxides. Thus, if extrapolated to the in vivo situation, it is reasonable to suppose that the toxicological properties of $\mathrm{PhSeSePh}$, in addition to a direct interaction with thiol groups of proteins such as $\delta$-ALA-D, may be related, in part, to its oxidation to seleninic acid after reaction with endogenous peroxides. However, since seleninic acid is an extremely reactive compound, the inhibition of $\delta$-ALA-D will occur only if reaction of $\mathrm{PhSeSePh}$ with hydroperoxides takes place in the cytosol in close proximity to the enzyme.

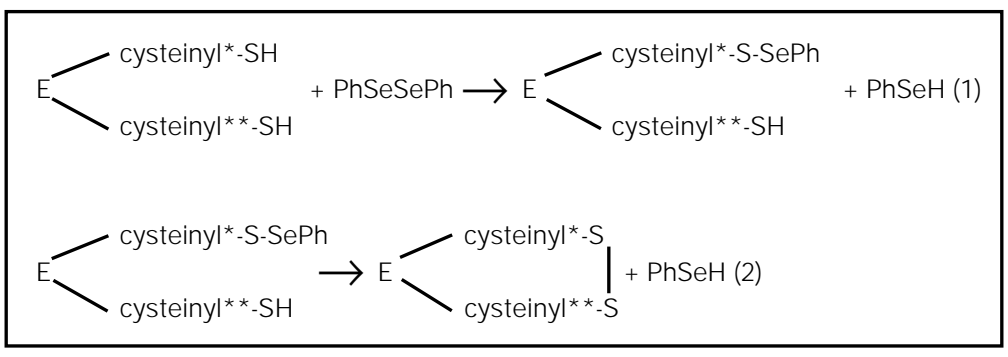




\section{References}

1. Painter EP (1941). The chemistry and toxicity of selenium compounds with special reference to the selenium problem. Chemical Reviews, 28: 179-213.

2. Stekol J A (1942). Selenium tetracysteine. J ournal of the American Chemical Society, 64: 1742.

3. Tsen CC \& Tappel AL (1958). Catalytic oxidation of glutathione and other sulphydryl compounds by selenite. J oumal of Biological Chemistry, 233: 1230-1232.

4. Ganther HE (1968). Selenotrisulfides. Formation by reaction of thiols with selenious acid. Biochemistry, 7: 2898-2905.

5. Ganther HE (1971). Reduction of the selenotrisulfide derivative of glutathione to a persulfide analog by glutathione reductase. Biochemistry, 10: 4089-4098.

6. Caldwell KA \& Tappel AL (1968). Acceleration of sulphydryl oxidations by selenocystine. Archives of Biochemistry and Biophysics, 127: 259-262.

7. Günther WHH (1967). Methods in selenium chemistry. III. The reduction of diselenides with dithiothreitol. J ournal of Organic Chemistry, 32: 3931-3933.

8. Ganther HE \& Kraus RJ (1984). Oxidation states of glutathione peroxidase. Methods in Enzymology, 107: 593-602.

9. Ursini $F \&$ Bindoli $A$ (1987). The role of selenium peroxidases in the protection against oxidative damage of membranes. Chemistry and Physics of Lipids, 44: 255276.

10. Forstrom J W, Zakowski JJ \& Tappel AL (1978). Identification of catalytic site of rat liver glutathione peroxidase as selenocysteine. Biochemistry, 17: 2639-2644.

11. Wilson SR, Zucker PA, Huang RRC \& Spector A (1989). Development of synthetic compounds with glutathione peroxidase activity. J ournal of the American Chemical Society, 111: 5936-5939.

12. Engman L, Stern D, Cotgreave IA \& Anderson M (1992). Thiol peroxidase activity of diaryl ditellurides as determined by a H-NMR method. J ournal of the American Chemical Society, 114: 97379743.

13. Müller $A$, Cadenas $E$, Graf $P \&$ Sies $H$ (1984). A novel biologically active organoselenium compound. 1. Glutathione peroxidase-like activity in vitro and antioxidant capacity of PZ-51 (Ebselen). Biochemical Pharmacology, 33: 3235-3239.

14. Wendel $A$, Fausel $M$, Safayi $H \&$ Otter $R$ (1984). A novel biologically active organoselenium compound. 2. Activity of PZ-51 in relation to glutathione peroxidase. Bio- chemical Pharmacology, 33: 3241-3245.

15. Müller A, Gabriel H \& Sies H (1985). A novel biologically active selenoorganic compound. 4. Protective glutathione-dependent effect of PZ 51 (Ebselen) against ADP-Fe-induced lipid peroxidation in isolated hepatocytes. Biochemical Pharmacology, 34: 1185-1189.

16. Barbosa NBV, Rocha JBT, Zeni G, Emanuelli $\mathrm{T}$, Beque $\mathrm{MC} \&$ Braga $\mathrm{AL}$ (1998). Effect of organic forms of selenium on $\delta$-aminolevulinate dehydratase from liver, kidney and brain of adult rats. Toxicology and Applied Pharmacology, 49: 243-253.

17. J acques-Silva MC, Nogueira CW, Broch LC, Flores EMM \& Rocha JBT (2001). Diphenyl diselenide and ascorbic acid change deposition of selenium and ascorbic acid in liver and brain of mice. Pharmacology and Toxicology, 88: 119-125.

18. Rodrigues ALS, Belinasso ML \& Dick $T$ (1989). Effect of some metal ions on blood and liver delta-aminolevulinate dehydratase of Pimelodus malacatus (Pisces, Pimelodidae). Comparative Biochemistry and Physiology, 94B: 65-69.

19. Barnard GF, Itoh R, Hohberger LH \& Shemin D (1977). Mechanism of porphobilinogen synthase - Possible role of essential thiol groups. J oumal of Biological Chemistry, 252: 8965-8974.

20. Emanuelli T, Rocha JBT, Pereira ME, Porciuncula LO, Morsch VM, Martins AF \& Souza DOG (1996). Effects of mercuric chloride intoxication and 2,3-dimercaptopropanol (BAL) treatment on delta-aminolevulinate dehydratase from brain, kidney and liver of adult mice. Pharmacology and Toxicology, 79: 136-143.

21. Markham GD, Myers CM, Harris KA, Volin J RM \& J affe EK (1993). Spatial proximity and sequence localization of the reactive sulfhydryls of porphobilinogen synthase. Protein Science, 2: 71-79.

22. Rocha JBT, Rocha LK, Emanuelli T \& Pereira ME (2001). Effect of mercury chloride and lead acetate during the second stage of rapid post-natal brain growth on the behavioral response to chlorpromazine and $\delta$-ALA-D activity in weaning rats. Toxicology Letters, 125: 143-150.

23. J affe EK (1995). Porphobilinogen synthase, the first source of heme's asymmetry. J ournal of Bioenergetics and Biomembranes, 27: 169-179.

24. Sassa S, Fujita H \& Kappas A (1989). Genetic and chemical influences on heme biosynthesis. In: Kotyk A, Skoda J , Paces
$\mathrm{V} \&$ Kotska V (Editors), Highlights of Modern Biochemistry. Vol. 1. VSP, Utrecht, Netherlands, 329-338.

25. Bechara EJ H, Medeiros MHG, Monteiro HP, Hermes-Lima M, Pereira B, Demasi $M$, Costa CA, Adballa DSP, Onuki J, Wendel CMA \& Masci PD (1993). A free radical hypothesis of lead poisoning and inborn porphyrias associated with 5-aminolevulinic acid overload. Química Nova, 16: 385-392.

26. Pereira B, Curi R, Kokubun E \& Bechara EJ (1992). 5-Aminolevulinic acid-induced alterations of oxidative metabolism in sedentary and exercise-trained rats. J ournal of Applied Physiology, 72: 226-230.

27. Senior NM, Brocklehurst $K$, Cooper J B, Wood SP, Erskine $\mathrm{P}$, Shooling-J ordans PM, Thomas PG \& Warren MJ (1996). Comparative studies on the 5-aminolevulinic acid dehydratase from Pisum sativum, Escherichia coli and Saccharomyces cerevisiae. Biochemical J oumal, 320: 401412.

28. Goudgaon NM \& Schinazi RF (1991). ACtivity of acyclic 6-(phenylselenenyl) pyrimidine nucleosides against human immunodeficiency viruses in primary lymphocytes. J ournal of Medicinal Chemistry, 34: 3305-3309.

29. Kice J L \& Lee WS (1978). Oxidation-reduction reactions of organoselenium compounds. 1. Mechanism of reaction between seleninic acid and thiols. J ournal of the American Chemical Society, 100: 5094-5102.

30. Emanuelli T, Rocha J BT, Pereira ME, Nascimento PC, Souza DOG \& Beber FA (1998). Delta-aminolevulinate dehydratase inhibition by 2,3-dimercaptopropanol is mediated by chelation of zinc from a site involved in maintaining cysteinyl residues in a reduced state. Pharmacology and Toxicology, 83: 95-103.

31. Sassa S (1982). Delta-aminolevulinic acid dehydratase assay. Enzyme, 28: 133-145.

32. Bradford MM (1976). A rapid and sensitive method for the quantification of microgram quantities of protein utilizing the principle of protein-dye binding. Analytical Biochemistry, 72: 248-254.

33. Dixon M \& Webb EC (1964). Enzymes. 2nd edn. Longmans, London and Colchester, UK.

34. Ayrey G, Barnard D \& Woodbridge DT (1962). The oxidation of organoselenium compounds by ozone. Journal of the American Chemical Society, 84: 20892099. 
35. McCullough J D \& Gould ES (1949). The dissociation constants of some-substituted benzeneseleninic acids. J oumal of the American Chemical Society, 71: 674678.

36. Bevan DR, Bodlaender $P \&$ Shemin $D$ (1980). Mechanism of porphobilinogen synthase. Requeriment of $\mathrm{Zn}^{2+}$ for enzyme activity. J oumal of Biological Chemistry, 256: 2030-2035.

37. Dent AJ, Beyersmann D, Block C\&
Hasnais SS (1990). Two different zinc sites in bovine 5-aminolevulinate dehydratase distinguished by extended X-ray absorption fine structure. Biochemistry, 29: 7822-7828.

38. Maciel EN, Bolzan R, Braga AL \& Rocha J BT (2000). Diphenyl diselenide and diphenyl ditelluride differentially affect $\delta$ aminolevulinate dehydratase from liver, kidney and brain of mice. J ournal of Biochemical and Molecular Toxicology, 14:
310-319.

39. Chaudiere J , Wilhelmsen EC \& Tappel AL (1984). Interaction of gold (1) with the active-site of selenium glutathione-peroxidase. J ournal of Biological Chemistry, 259: 1043-1050.

40. House KL, Dunlap RB, Odom J D, Wu Z-P $\&$ Hilvert D (1992). Structural characterization of selenosubtilisin by Se-77 NMRspectroscopy. J ournal of the American Chemical Society, 114: 8573-8579. 